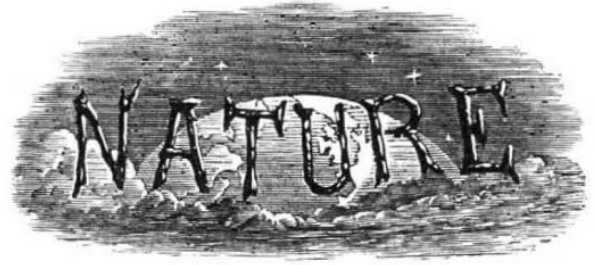

THURSDAY, OCTOBER 7, I920.

Editorial and Publishing Offices:

MACMILLAN \& CO., LTD.,

ST. MARTIN'S STREET, LONDON, W.C. 2.

Advertisements and business letters should be addressed to the Publishers.

Editorial communications to the Editor.

Telegraphic Address: PHUSIS, LONDON.

Telephone Number: GERRARD 8830.

\section{The Metric System and International} Trade.

I the year 1917, when the nation was in the throes of war, a committee of the Conjoint Board of Scientific Societies arrived at certain conclusions on the question of the compulsory adoption of the metric system in Great Britain, but, unfortunately for the committee, the publication of its findings has been delayed until the present time. ${ }^{1}$ During the intervening three years our attention has been transferred from warlike to peaceful occupations, and the nation at large is now much more alive to the necessity of improving our commercial equipment for the impending vital struggle to recover and expand our overseas trade in order that we may "pay for the war." The committee apparently appreciates this change in the general atmosphere, and has accordingly published an apologetic prefatory note, from which it incidentally appears that the chief source of its evidence was the "Report on Commercial and Industrial Policy after the War." It may be recalled that Lord Balfour of Burleigh, the chairman of that committee, naively admitted afterwards, during a House of Lords debate on decimal coinage, that his committee had been so overloaded with other problems that the subject of decimalisation had

1 "Report on Compulsory Adoption of the Metric System in the United Kingdom." Submitted by the Metric Committee appointed by the Conjoint Buard of Scientific Soc eties, and published on the authority of the Committee. Pp. 70. (London: Eoard of Scientific Societies, Koyal Society, nd.) Price is.

NO. 2658 , VOL. IO6] possibly not received the attention it really deserved.

Unfortunately, this preface will probably escape general attention, because so many readers will skip it, glance through the report, and really note only the final "Recommendations," which are published on p. 35 of the committee's report, and are about as unsatisfactory as they could well be. Hence we have the lay Press to-day stating that British men of science have denounced the metric system, whereas actually the report has not been adopted by the Conjoint Board, and is issued solely on the authority of the committee. Moreover, in par. 88 of the report the committee recognises "the intrinsic superiority of the metric system in scientific and technical work."

One looks in vain for a note in these recommendations to the effect that the metric system is (a) already universally employed in science; $(b)$ the practical basis of industry in many countries the trade of which we seek; $(c)$ already legally recognised throughout the civilised world; and that accordingly, in the interests of the scientific permeation of industry, as well as of the expansion of our overseas trade, everything possible should be done to encourage its use. Instead of this, we find the committee recommending "that the British system of units of weights and measures be retained in general use in the United Kingdom," which is tantamount to suggesting that British manufacturers engaged in world-wide trade must continue indefinitely to employ two systems--the British for home trade and the metric for overseas tradeinvolving an increasing volume of misunderstandings and unnecessarily wasted time spent in conversions from one system to the other. If the British manufacturer can, as he already does, sell a portion of his output under metric description, he can obviously sell the whole of it on that basis, and he should clearly be encouraged to conduct all his business in one language of quantity instead of two.

In par. 82 of the report the following constructive sentence occurs: "In the opinion of the committee it would be to the advantage of British industry if the manufacture of all machinery and apparatus of new types were to be established as a matter of course in the metric system; and that this practice should be directed and encouraged by specification in this system for Government and official work"; and yet no reference is made to this in their final "recommendations," which, instead, include a plea for the continued use of British units by Departments of State. 
According to the second recommendation, the committee apparently views with equanimity the perpetuation of our use of two systems where one would suffice for all purposes. In the third recommendation the committee suggests the decimalisation of the British units of weight and measure, thus supporting a proposal roundly condemned by a select committee of the House of Commons which, in 1862 , reported that "It would involve almost as much difficulty to create a special decimal system of our own as simply to adopt the metric system in common with other nations. And if we did so create a national system we would, in all likelihood, have to change it again in a few years, as the commerce and intercourse between nations increased, into an international one."

Our choice to-day rests between (I) the continued use of a dual system (because we must employ the metric system in an increasing proportion of our business, whether we like it or not), and (2) the establishment of the metric system as the universal language of quantity (involving the gradual abandonment of the Imperial system which, by reason of its manifest defects, is so obviously unsuitable for universal adoption).

It is sheer insularity which makes us cling to the first course and, regarding the alternative, the committee of the Conjoint Board states in par. 5o of its report (but omits from the "recommendations ") that "It will be sufficient for the purpose of this inquiry to admit unreservedly that the metric system of weights and measures is the only system which has considerable claims to be truly international, and that it is the only system to which a change could reasonably be made should any country propose to abolish its existing national system."

Some further Government action is clearly required beyond the Act of 1897 , but it does not necessarily follow that the next step need be the adoption of legislation of a compulsory character. The Government could do very much to encourage the more widespread use of the system by its employment in Government specifications and by a declaration that ultimately at some future date (not necessarily fixed at present) the metric system would become the sole legal system in this country. Many manufacturers would be thereby stimulated to establish all their new standards and their revisions of old standards in terms of the metric system, and there would be nothing to prevent them from continuing to manufacture their existing standards in the British system and describing NO. 2658 , VOL. IO6] them for sale in terms of the metric system, as they already have done for so many years. We should thus progress beyond the present passive permission, through a period of intensive encouragement, to the final stage in which the metric system would become the sole legal system of weights and measures, when "compulsion" need be applied only to the stragglers who had failed to adopt it voluntarily.

It is satisfactory to note that with regard to decimal coinage the committee "sees no serious objection in principle" to the proposals for decimalising the $£$ sterling, and it may be interested to know that the revision of Lord Southwark's Bill is now under consideration with a view to the removal of some of the practical difficulties to which the committee refers. In the meantime we may perhaps be permitted to remark that it is futile to talk about "preserving the credit of the penny" at a time like the present, when the failure of the penny to meet modern conditions is so very obvious.

Harry Allcock.

\section{The Study of Live Embryos.}

Contributions to Embryology. Vol. ix., Nos. 27 to 46. A Memorial to Franklin Paine Mall. (Publication No. 272.) Pp. $\mathrm{v}+554+$ plates. (Washington: The Carnegie Institution of Washington, 1920.)

I ONG before the war it was being realised in England that the centre of embryological research, at least so far as concerns inquiries into the developmental stages of the human body, was shifting from the laboratories of Germany to those of the United States. The transference was the work of one man-the late Prof. F. P. Mall, who died in 1917 at the age of fifty-five. Prof. Mall stocked the new and highly equipped anatomical laboratories of the United States with young men and women who had served their apprenticeship with him in the anatomical department of Johns Hopkins Hospital, Baltimore. In 19 I 8 he would have reached the twenty-fifth anniversary of his appointment at Baltimore, and his pupils, "in recognition of his inspiring leadership, and in response to the strong feeling of affection with which they had come to regard him," intended to mark the occasion by dedicating to him a volume of their most recent investigations. These essays, owing to his untimely death, have now to appear as a memorial volume, and the sense of regret that Prof. Mall did not live to study it will be felt as acutely on this side of the Atlantic as on the 